\title{
Pumpkinseed sunfish (Lepomis gibbosus) invasions facilitated by introductions and nature management strongly reduce macroinvertebrate abundance in isolated water bodies
}

\author{
H. van Kleef - G. van der Velde \\ R. S. E. W. Leuven · H. Esselink
}

Received: 17 August 2006/Accepted: 21 January 2008/Published online: 5 February 2008

(C) The Author(s) 2008

\begin{abstract}
The pumpkinseed sunfish, Lepomis gibbosus, originates from Eastern North America and was introduced to the Netherlands in 1902 as an aquarium and garden pond fish. At present the pumpkinseed is widely spread throughout the Netherlands and occurs in a variety of aquatic habitats. It is especially abundant in moorland pools, fishing ponds and urban waters. Strong population development of the pumpkinseed appears to be facilitated by nature management practices in existing ponds (the removal of accumulated organic matter and macrophytes) and by creating new ponds. These measures enhance suitable breeding habitats that are free of competitors and predators. Isolated waters harbouring pumpkinseed were more
\end{abstract}

H. van Kleef · H. Esselink

Bargerveen Foundation, Radboud University,

Toernooiveld 1, 6525 ED Nijmegen, The Netherlands

H. van Kleef · R. S. E. W. Leuven

Department of Environmental Science, Institute for Water and Wetland Research, Radboud University,

Toernooiveld 1, 6525 ED Nijmegen, The Netherlands

G. van der Velde $\cdot$ H. Esselink

Department of Animal Ecology and Ecophysiology, Institute for Water and Wetland Research, Radboud University, Toernooiveld 1, 6525 ED Nijmegen,

The Netherlands

G. van der Velde $(\bowtie)$

National Museum of Natural History, Naturalis, P.O. Box 9517, 2300 RA Leiden, The Netherlands

e-mail: g.vandervelde@science.ru.nl often situated close to human habitation and infrastructure than could be expected based on the distribution of randomly selected isolated waters, identifying introductions as an important dispersal mechanism. In order to minimize the chances of introductions, planning of nature management practices should be done at distances over $250 \mathrm{~m}$ from human habitation and $100 \mathrm{~m}$ from infrastructure. Macroinvertebrate abundance in pools populated by pumpkinseed was eighty three percent lower than in pools without pumpkinseed, probably due to opportunistic feeding and high pumpkinseed abundances. Currently there is little experience with pumpkinseed control. However, options to be explored include: decreasing depth of colonized waters by filling them with soil allowing them to occasionally dry up, introducing native competitors and predators and the use of biodegradable piscicides. In addition, limitation of the sale of pumpkinseed is required as well as public education on the consequences of introducing exotic species.

Keywords Non-native species · Invasiveness · Nature management · Consequences .

Ecological restoration $\cdot$ Moorland pools

\section{Introduction}

The pumpkinseed sunfish, Lepomis gibbosus, is native to the Atlantic Slope region of North America (Scott 
and Crossman 1973). At the end of the 19th century it was first imported in Europe for recreational fishery and as an aquarium and garden pond fish and now it is one of the most successfully introduced fish species (Holčik 1991; Garcia-Berthou and Moreno-Amich 2000). In the Netherlands, pumpkinseed have been bred in captivity since 1902 (Looijen 1948). Following its release, pumpkinseed were primarily restricted to interconnected running waters throughout the country (De Nie 1996), but were recorded from a few isolated waters (Leuven and Oyen 1987). Pumpkinseed abundance in running waters is generally low (Klaar et al. 2004; Hoogerwerf et al. 2005; This study). However, in recent years the species has been encountered with increasing frequency and in high abundance in isolated lentic waters and especially in moorland pools, that are subject to specific management aims.

Intact moorland pools are characterized by a sandy substrate, low alkalinity and low productivity due to carbon, phosphorus and nitrogen limitation. During the twentieth century many of these pools have been impacted by acidification and eutrophication (Arts and Leuven 1988; Leuven et al. 1992). Acidification initially enhanced dissolved $\mathrm{CO}_{2}$ concentrations, thus removing carbon as a limiting factor for fast-growing plant species such as Juncus bulbosus and Sphagnum. In many moorland pools primary production was further enhanced by agricultural run-off of phosphorus and deposition of airborne nitrogen. As ongoing acidification also decreased decomposition rates (Kelly et al. 1984; Leuven and Wolfs 1988), organic debris accumulated. These changes caused characteristic plant and animal species to decline or to disappear (Roelofs 1983; Leuven et al. 1986a, 1987; Arts and Leuven 1988; Arts et al. 1990). In order to counteract the effects of acidification and eutrophication in moorland pools (Brouwer and Roelofs 2001), management practices consisting of the removal of accumulated organic matter and macrophytes and the sod cutting of littoral shores have been implemented. This exposes bare mineral soils which facilitates the return of characteristic plant species.

Evidence of intentional release of non-native fish in Dutch moorland pools comes from repeated observations of common garden pond plants, such as Ceratophyllum demersum and Azolla filiculoides, in pools populated by pumpkinseed (unpublished data $H$. van Kleef). This indicates dumping of aquaria or garden pond contents, as these plant species cannot survive in these oligotrophic, low alkaline and often acidic waters. Humans have been demonstrated to be the main vector in the dispersal of non-native fish (Trombulac and Frissell 2000; Copp et al. 2005) and Copp et al. (2005) demonstrated that the likelihood of introduction is related to the accessibility of the pond. For the planning of nature management it is wise to select pools, that are least susceptible to introductions. Therefore, it is important to assess the accessibility and hereby the vulnerability of ponds to introductions.

The pumpkinseed is listed among the top ten introduced fish species with adverse ecological effects (Casal 2006). It has been reported to be responsible for the decline of other fish species (Welcomme 1988) as well as gastropods (Osenberg et al. 1992). Because of the importance of moorland pools for the conservation of native aquatic species, the aim of the present study was to assess the risk of pumpkinseed invasion and the ecological impact on native species in these waters. Our specific objectives were to: (1) test whether accessibility of Dutch isolated waters influenced the chance of pumpkinseed introductions; (2) examine if there was a relationship between pumpkinseed invasiveness and nature management practices and (3) assess the impact of pumpkinseed on fauna abundance.

\section{Materials and methods}

\section{Distribution data}

Distributional data of pumpkinseed were obtained from De Nie (1996), national and regional databases (i.e. Foundation RAVON, Dutch National Federation of Anglers and Natuurhistorisch Genootschap in Limburg), and by surveying biologists and nature managers. For each location identified, we documented whether the location was isolated or connected to other waters. For isolated sites data was obtained from terrain owners on management practices involved in habitat management and pumpkinseed control. Distinguished types of habitat management were: (1) removal of organic matter and macrophytes, (2) digging of pools, (3) sod cutting of shores and (4) no management. Isolated waters were further divided into moorland pools, meadow ponds, fishing and urban ponds and sand excavation pits. Pumpkinseed abundance was derived directly 
from the available databases or estimated based on the number of recorded specimens. Pumpkinseed abundance was divided into four categories (1 recorded specimen: rare, 2-4: frequent, 5 or more: abundant, number of fish not recorded: unknown). Twenty seven isolated waters were visited in 2007 in order to check the reported population status. These assessments were made during the breeding season (May and June) when territorial males guarding their nest are easily spotted (Fig. 1). The census consisted of counting territorial male pumpkinseed along a $50 \mathrm{~m}$ stretch of shore. Data were converted into categories: rare (1-5 territorial males), frequent (5-15 territorial males) and abundant ( $>15$ territorial males). Our census data revealed that abundance estimated from databases and other sources was accurate in 23 of 27 cases, whereas pumpkinseed abundance of four sites classified as "abundant" based on databases was classified as "rare" based on the 2007 census. For comparison of abundance in connected and isolated waters, we used all available data (databases, 2007 survey and other sources),

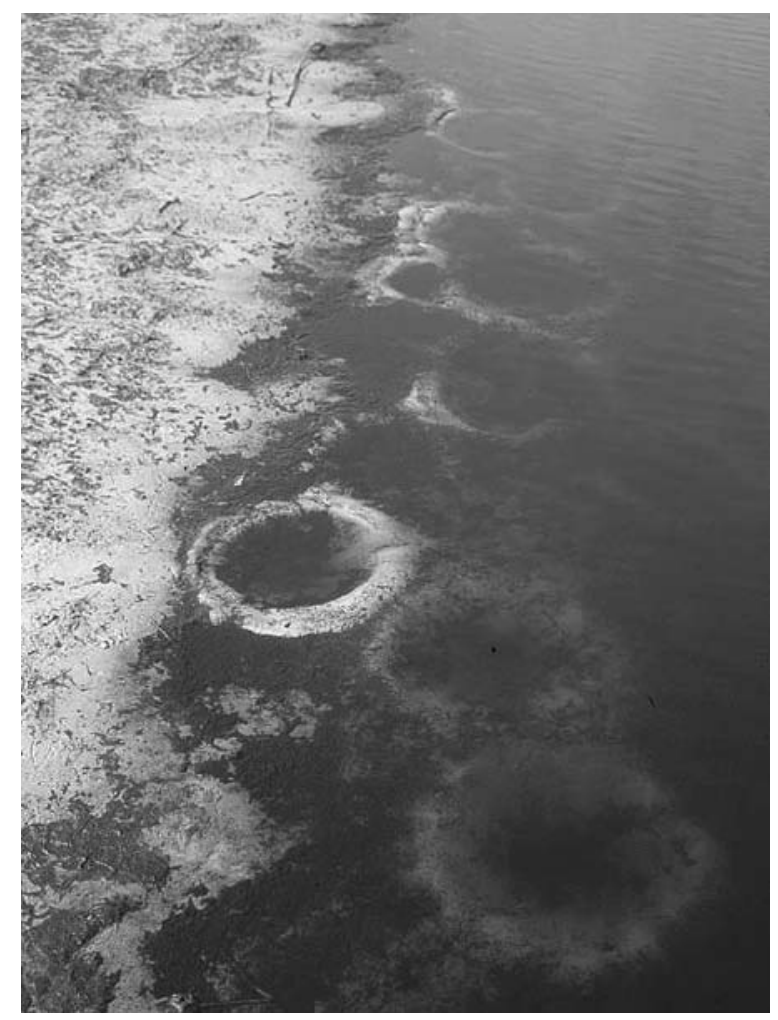

Fig. 1 Nests of male pumpkinseed sunfish (Lepomis gibbosus) on the shore of a dredged moorland pool whereas for the analyses of relationship between abundance and nature management, the confirmed data from the 2007 survey were used. Difference in pumpkinseed abundance between connected and isolated waters was tested with a $\chi^{2}$-test. A Kruskal-Wallis test was used to test for overall differences in abundance between different types of habitat management and $\chi^{2}$-tests were used to compare individual management types.

In order to assess the influence of accessibility of Dutch isolated waters on pumpkinseed introductions, the distance of colonized isolated waters to urban settlements as well as roads and paths was determined and compared with the distance to settlements and infrastructure of a random selection of 100 isolated waters, within a $10 \mathrm{~km}$ radius of the colonized waters. This $10 \mathrm{~km}$ radius was chosen to correct for the non-random distribution of isolated waters in the Netherlands and moorland pools, especially (Arts et al. 1989). Distances were measured from topographical maps (scale 1:25,000). For different distance intervals we calculated the percentage of water bodies falling into that interval. This was also done cumulative with increasing distance, in order to calculate the ratio between cumulative percentages of pumpkinseed waters and randomly selected water bodies. Differences in the distributions of isolated pumpkinseed waters and the randomly selected waters were tested on the cumulative number of water bodies using $\chi^{2}$-tests at $250 \mathrm{~m}$ from urban settlements and $100 \mathrm{~m}$ distance from roads or paths.

\section{Environmental impact}

To assess effects of pumpkinseed of fauna abundance, in May 2007 macroinvertebrates were sampled from eight pools, all of them heavily disturbed (dredged) or newly created. Four of these pools housed large populations of pumpkinseed (Kranenbroek-pool-1 $\left(51^{\circ} 6^{\prime} 11.5^{\prime \prime} \mathrm{N}, \quad 5^{\circ} 54^{\prime} 57.5^{\prime \prime} \mathrm{E}\right), \quad$ Kranenbroek-pool-2 $\left(51^{\circ} 6^{\prime} 11.5^{\prime \prime} \mathrm{N}, 5^{\circ} 54^{\prime} 57.5^{\prime \prime} \mathrm{E}\right)$, Haeselaarsbroek (51 ${ }^{\circ} 4^{\prime}$ $\left.27.9^{\prime \prime} \mathrm{N}, 5^{\circ} 55^{\prime} 6.6^{\prime \prime} \mathrm{E}\right)$, Uden-urban pond $\left(51^{\circ} 40^{\prime} 29.8^{\prime \prime}\right.$ $\left.\mathrm{N}, 5^{\circ} 38^{\prime} 31.6^{\prime \prime} \mathrm{E}\right)$ ), whereas the other pools did not contain pumpkinseed (Nuenen-IJsbaan $\left(51^{\circ} 29^{\prime} 7.6^{\prime \prime} \mathrm{N}\right.$, $\left.5^{\circ} 32^{\prime} 50.9^{\prime \prime} \mathrm{E}\right)$, Banen ( $\left.51^{\circ} 16^{\prime} 11.9^{\prime \prime} \mathrm{N}, 5^{\circ} 47^{\prime} 56.2^{\prime \prime} \mathrm{E}\right)$, Broekse Wiel-1 $\left(51^{\circ} 43^{\prime} 46.1^{\prime \prime} \mathrm{N}, 5^{\circ} 45^{\prime} 55.7^{\prime \prime} \mathrm{E}\right)$, Broekse Wiel-2 (51 $\left.43^{\prime} 46.1^{\prime \prime} \mathrm{N}, 5^{\circ} 45^{\prime} 55.7^{\prime \prime} \mathrm{E}\right)$. The pools were slightly acid to alkaline $(\mathrm{pH}$ between 5.2 
and 9.6), oligotrophic (ortho-phosphate between 0.00 and $0.48 \mu \mathrm{mol} \mathrm{l}^{-1}$ and total-N between 1.39 and $77.70 \mu \mathrm{mol}^{-1}$ ) and their surface area ranged from 6.5 are to 2 ha. Pools without and with pumpkinseed did not differ in $\mathrm{pH}$, alkalinity, $\mathrm{NH}_{4}^{+}, \mathrm{NO}_{3}^{-}$and surface area (Mann-Whitney U tests). Ortho-phosphate was higher in pools without pumpkinseed (average $0.37 \mu \mathrm{mol}^{-1}$ ) compared to pools with pumpkinseed (average $\left.0.01 \mu \mathrm{mol} \mathrm{^{-1 }}\right)$, but still oligotrophic $\left(<0.5 \mu \mathrm{mol} \mathrm{l}^{-1}\right)$. Sampling was done using a $20 \times 30 \mathrm{~cm}$ pond net with $0.5 \mathrm{~mm}$ mesh size. At each site macroinvertebrates were sampled using a stratified random sampling procedure. Sampling effort per pool was $1.5 \mathrm{~m}^{2}$. Samples were transported to the laboratory and stored at $4{ }^{\circ} \mathrm{C}$ to minimize mortality. Samples were washed over three sieves with 2,1 , and $0.5 \mathrm{~mm}$ mesh sizes, respectively and sorted in white trays within two days after sample collection and preserved until identification. Macroinvertebrates were identified to the level of family in the case of Diptera or order in the case of other Insecta, Isopoda, Tricladida, Gastropoda, Hirudinea, Oligochaeta, Araneida and Acarina. Differences in densities of taxa at sites with and without pumpkinseed were tested with Mann-Whitney U tests.

In order to determine if observed differences in densities of taxa in sites with and without pumpkinseed could be explained by pumpkinseed predation, we examined the diet of pumpkinseed in a Dutch moorland pool. In autumn 2003, during an attempt to remove all the pumpkinseed from the moorland pool Rauwven $\left(51^{\circ} 35^{\prime} 3.1^{\prime \prime} \mathrm{N}, 5^{\circ} 37^{\prime} 43.0^{\prime \prime} \mathrm{E}\right), 18$ specimens from three different size classes (total length ranges 4.9-5.8, 8.8-9.7 and 11-13 cm) were collected. Their intestines were extracted and examined for remains of prey, which were identified to the level of family in the case of Diptera, order in the case of other Insecta and Arachnida or class in the case of Collembola.

\section{Results}

Pumpkinseed distribution, abundance and relation with human settlements and activities

The pumpkinseed is widely distributed in the Netherlands, especially in the southern part of the country (Fig. 2). It has been recorded from 69 interconnected waters and 42 isolated water bodies (Table 1). In contrast to connected waters, pumpkinseed were more often abundant in isolated waters $\left(\chi^{2}\right.$-test, $P<0.0001$, Table 1). In a single moorland pool (0.3 ha surface area) over 5,000 specimens were caught in $4 \mathrm{~h}$ of seine netting. Although the species has become established in different types of waters, it is generally most abundant in moorland pools and fishing and urban ponds (Table 2). Eighty eight percent of the isolated waters with a high pumpkinseed abundance have been excavated (mainly urban ponds) or dredged (moorland pools), whereas only $22 \%$ of the waters with less rigorous (sod cutting) or no nature management had a high pumpkinseed abundance. Pumpkinseed abundance differed by type of management (Table 3, Kruskal-Wallis test, $P=0.003)$. In dredged pools pumpkinseed were more abundant, than under other types of management. Whereas, abundance in newly created pools was higher than in pools with less rigorous (sod cutting) and no nature management (Table 3 ).

In isolated waters pumpkinseed were recorded up to $3,800 \mathrm{~m}$ from human habitation and $175 \mathrm{~m}$ from the nearest road or path. Thirty eight percent of the waters with pumpkinseed were located less than $250 \mathrm{~m}$ from settlements, whereas $69 \%$ of the pumpkinseed waters were located within $50 \mathrm{~m}$ for roads or paths. Isolated waters harbouring pumpkinseed were more often situated close to human habitation (distance less than $250 \mathrm{~m}, \chi^{2}$-test, $P=0.05$ ) and infrastructure (distance less than $100 \mathrm{~m}, \chi^{2}$-test, $P=0.05)$ than could be expected based on the distribution of 100 randomly selected isolated waters (Fig. 3a,b).

\section{Pumpkinseed impacts}

Average macroinvertebrate abundance in ponds with pumpkinseeds was $83 \%$ lower than in ponds without pumpkinseeds. The abundance of eight invertebrate taxa (Tricladida, Hirudinea, Oligochaeta, Odonata, Heteroptera, Chironomidae, Ceratopogonidae and Trichoptera) was significantly lower in pumpkinseed ponds (Mann-Whitney U-test, $P<0.05$, Table 4), whereas no taxa were found to be more abundant. The abundance of water mites (Acarina) was similar in ponds with and without pumpkinseed.

Eleven different types of prey were identified in pumpkinseed intestines collected in the Rauwven (Fig. 4). In terms of prey numbers, chironomids and 
Fig. 2 Distribution of the pumpkinseed in Europe by country based on Copp and Fox (2007) and its distribution in the Netherlands. Circles: isolated waters, triangles: connected waters; small symbols: 1 location, intermediate symbols: 2-4 locations and large symbols: 5 or more locations in squares of $10 \times 10 \mathrm{~km}$

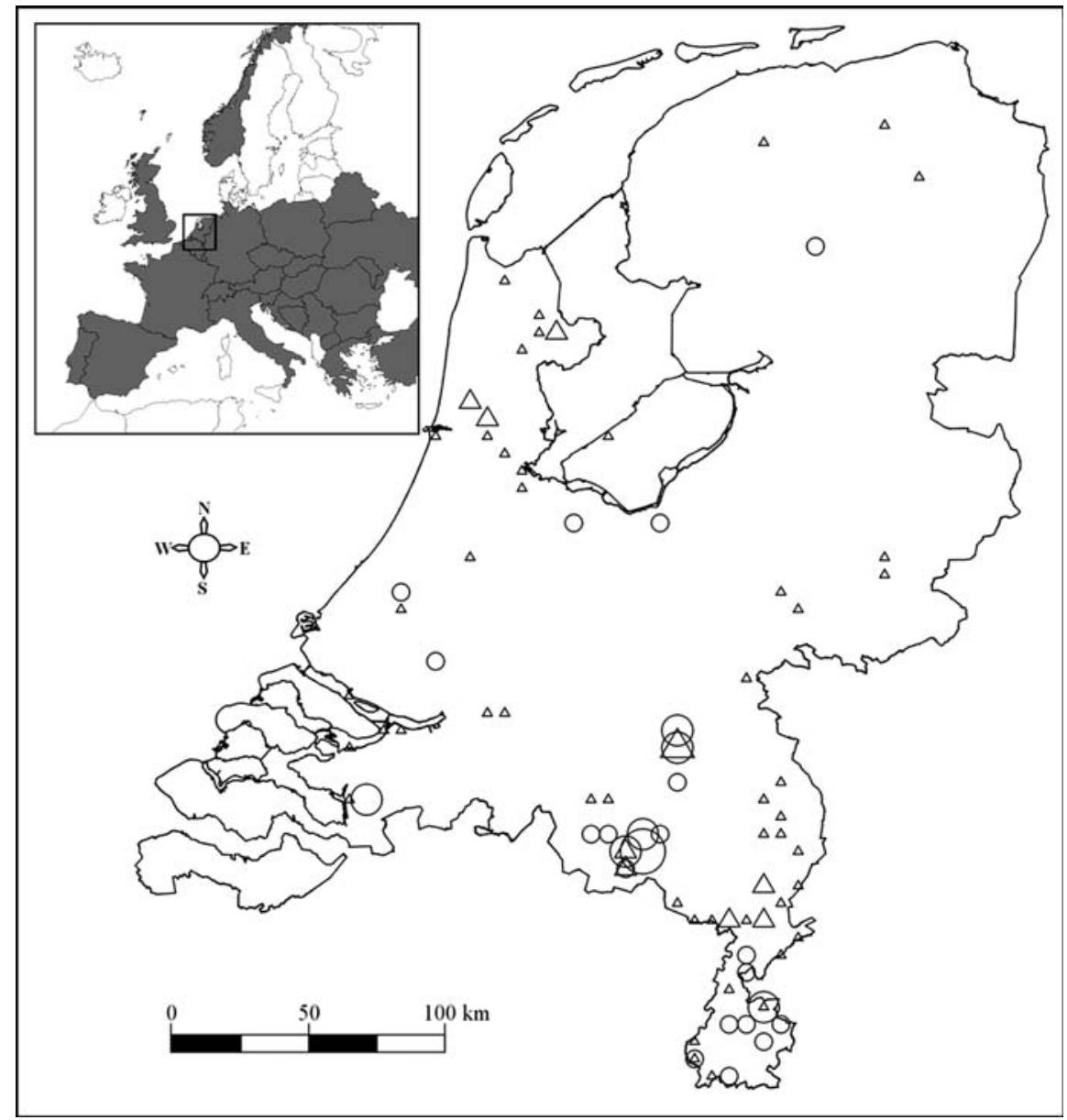

Table 1 Occurrence (\%) and abundance of pumpkinseed in isolated and connected waters in the Netherlands

\begin{tabular}{lll}
\hline & $\begin{array}{l}\text { Connected waters } \\
(\mathrm{N}=69)(\%)\end{array}$ & $\begin{array}{l}\text { Isolated waters } \\
(\mathrm{N}=42)(\%)\end{array}$ \\
\hline Abundant & 3 & 45 \\
Frequent & 13 & 12 \\
Rare & 61 & 38 \\
Unknown & 23 & 5 \\
\hline
\end{tabular}

microfauna constituted the majority of the diet. As with many gape-limited predators dietary choice shifts to large prey as the predator increases in size. Consequently the amount of zooplankton in the diet decreases and chironomids and other macroinvertebrates in the diet become more important. Seven out of eleven prey types were recorded with abundances higher than 25 individuals per $\mathrm{m}^{2}$ in ponds without pumpkinseed (Table 4), indicating a large overlap in diet and prey availability. The abundance of five of these taxa (Odonata, Heteroptera, Chironomidae, Ceratopogonidae and Trichoptera) was significantly lower in pumpkinseed ponds, making predation by pumpkinseed a plausible explanation for the apparent decrease of these taxa in the presence of pumpkinseed. No soft bodied prey (Tricladida, Hirudinea and Oligochaeta) were recorded in the diet, possibly due to rapid digestion without remains.

There is little experience in the Netherlands with pumpkinseed control. Three attempts (Schoappedobbe $52^{\circ} 57^{\prime} 10.569^{\prime \prime} \mathrm{N}, 6^{\circ} 15^{\prime} 32.206^{\prime \prime} \mathrm{E}$; a meadow pond near Uden $51^{\circ} 41^{\prime} 18.448^{\prime \prime} \mathrm{N}, 5^{\circ} 38^{\prime} 3.264^{\prime \prime} \mathrm{E}$ and a pond near Echt $51^{\circ} 6^{\prime} 11.688^{\prime \prime} \mathrm{N}, 5^{\circ} 54^{\prime} 6.075^{\prime \prime}$ E) were made by catching the fish using dip nets, electric fishing gear and seines. Only one of these attempts was successful. In the Rauwven $\left(51^{\circ} 35^{\prime} 6.309^{\prime \prime} \mathrm{N}\right.$, $5^{\circ} 37^{\prime} 48.254^{\prime \prime}$ E) pumpkinseed were successfully 
Table 2 Occurrence (\%) and abundance of pumpkinseed in different types of isolated waters in the Netherlands

\begin{tabular}{lllll}
\hline & $\begin{array}{l}\text { Moorland pools } \\
(\mathrm{N}=17)(\%)\end{array}$ & $\begin{array}{l}\text { Fishing and urban } \\
\text { ponds }(\mathrm{N}=8)(\%)\end{array}$ & $\begin{array}{l}\text { Meadow ponds } \\
(\mathrm{N}=1)(\%)\end{array}$ & $\begin{array}{l}\text { Sand excavation } \\
\text { pits }(\mathrm{N}=1)(\%)\end{array}$ \\
\hline $\begin{array}{l}\text { Abundant } \\
\text { Frequent }\end{array}$ & 71 & 38 & & 100 \\
Rare & 29 & 50 & 100 & \\
\hline
\end{tabular}

Table 3 Occurrence (\%) and abundance of pumpkinseed in isolated waters in relation to management practices

\begin{tabular}{lllll}
\hline & $\begin{array}{l}\text { Removal detritus and } \\
\text { macrophytes }^{\mathrm{a}}(\mathrm{N}=10)(\%)\end{array}$ & $\begin{array}{l}\text { Newly created } \\
(\mathrm{N}=8)(\%)\end{array}$ & $\begin{array}{l}\text { Sod cutting of shores } \\
(\mathrm{N}=4)(\%)\end{array}$ & $\begin{array}{l}\text { None }^{\mathrm{c}} \\
(\mathrm{N}=5)(\%)\end{array}$ \\
\hline $\begin{array}{l}\text { Abundant } \\
\text { Frequent }\end{array}$ & 100 & 50 & 25 & 20 \\
Rare & & 50 & 75 & 80 \\
\hline
\end{tabular}

Different letters indicate significant differences in pumpkinseed abundance $\left(\chi^{2}\right.$-test, $\left.P \leq 0.05\right)$

Table 4 Densities of aquatic macroinvertebrates (average number of individuals $\cdot \mathrm{m}^{-2} \pm \mathrm{SE}$ ) in moorland pools with and without pumpkinseed

\begin{tabular}{|c|c|c|}
\hline & $\begin{array}{l}\text { Without } \\
\text { pumpkinseed } \\
(\mathrm{N}=4)\end{array}$ & $\begin{array}{l}\text { With } \\
\text { pumpkinseed } \\
(\mathrm{N}=4)\end{array}$ \\
\hline Tricladida* & $13.2 \pm 6.1$ & $0.0 \pm 0.0$ \\
\hline Gastropoda* & $847.2 \pm 458.3$ & $188.0 \pm 167.1$ \\
\hline Hirudinea* & $11.5 \pm 5.1$ & $0.0 \pm 0.0$ \\
\hline Oligochaeta* & $170.7 \pm 58.2$ & $5.0 \pm 1.5$ \\
\hline Araneida & $6.7 \pm 6.2$ & $1.5 \pm 0.7$ \\
\hline Acarina & $107.2 \pm 38.4$ & $98.5 \pm 13.3$ \\
\hline Isopoda & $34.5 \pm 19.5$ & $1.3 \pm 1.3$ \\
\hline Odonata* & $40.3 \pm 6.7$ & $5.4 \pm 4.2$ \\
\hline Ephemeroptera & $49.7 \pm 39.3$ & $5.0 \pm 2.3$ \\
\hline Heteroptera* & $85.7 \pm 19.3$ & $8.3 \pm 3.7$ \\
\hline Megaloptera & $1.2 \pm 1.2$ & $0.0 \pm 0.0$ \\
\hline Coleoptera & $32.2 \pm 17.2$ & $3.0 \pm 1.1$ \\
\hline \multicolumn{3}{|l|}{ Diptera } \\
\hline Chaoboridae & $1.3 \pm 1.3$ & $0.0 \pm 0.0$ \\
\hline Culicidae & $0.2 \pm 0.2$ & $0.0 \pm 0.0$ \\
\hline Chironomidae* & $560.3 \pm 247.5$ & $31.7 \pm 5.9$ \\
\hline Ceratopogonidae* & $44.0 \pm 8.0$ & $4.2 \pm 1.5$ \\
\hline Tabanidae & $0.0 \pm 0.0$ & $0.2 \pm 0.2$ \\
\hline Trichoptera* & $25.2 \pm 22.3$ & $0.0 \pm 0.0$ \\
\hline Lepidoptera & $1.3 \pm 0.6$ & $0.0 \pm 0.0$ \\
\hline Total* & $2032.2 \pm 327.2$ & $352.1 \pm 8.6$ \\
\hline
\end{tabular}

* $P \leq 0.05$ (Mann-Whitney U-test)

eradicated by draining the pools and subsequently catching and removing the fish with seines. The remaining mud, puddles and hard-to-catch fish were covered by a layer of sand in order to kill the last fishes and to change the permanent pool into a temporary one.

\section{Discussion}

Although the pumpkinseed has been known to occur in the Netherlands since 1902 (Looijen 1948) and is nowadays widespread, its population densities are generally low. However, pumpkinseeds were found to be abundant in isolated waters which have been heavily disturbed by nature management practices (i.e. dredging) or which have been artificially created. Low pumpkinseed abundance in streams corresponds to reports from the UK, where reproduction only has been recorded in lentic waters from which nonreproducing stream populations are supplied (Klaar et al. 2004). In southern Europe, however, the species is also abundant in lotic waters (Godinho et al. 1997; Gutiérrez-Estrada et al. 2000). Copp and Fox (2007) and demonstrated that pumpkinseed invasiveness at lower latitudes may be attributed to warmer climatic conditions resulting in a higher fecundity (i.e. rapid maturation and faster juvenile growth). Increased fecundity may also be partially responsible for the observed high abundance of pumpkinseed in Dutch isolated water bodies as these waters have extensive shallow sun-exposed shores. Pumpkinseeds in a Dutch dredged moorland pool matured at age 2 (G.H. Copp unpublished), which is comparable to populations from southern Europe (reviewed in Copp et al. 2002). 

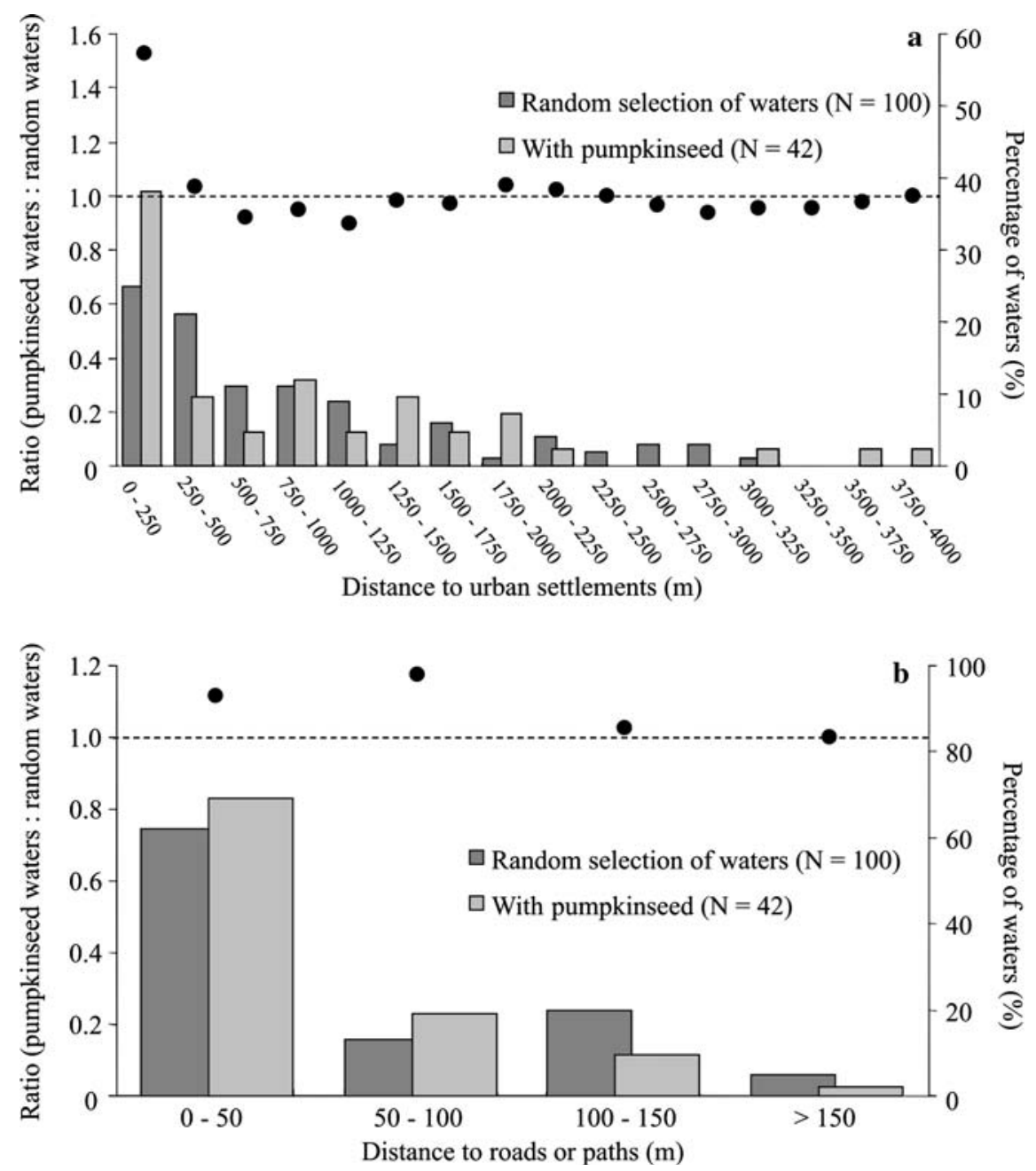

Fig. 3 Distribution of randomly selected isolated waters and isolated waters with pumpkinseed in relation to distance to human settlements (a) and roads or paths (b). Bars: Percentage of waters in different distance intervals. Dots: ratio cumulative

Favourable climatic conditions (i.e. rapid warming in spring and high temperatures in summer) are unlikely to be the only reason for pumpkinseed invasiveness in Dutch isolated waters, as high pumpkinseed abundance often coincided with specific management practices. These practices are actually likely to decrease the average water temperature as they expose mineral soils, which would increase water temperature less than the organic matter which covers soils of most undisturbed waters. High pumpkinseed abundance in dredged or newly created waters can possibly be attributed to an increased area of optimal spawning habitat (Fig. 1). (with increasing distance) percentage of waters with pumpkinseed: cumulative percentage randomly selected waters. Dotted line: equal distribution of waters with pumpkinseed and randomly selected waters

Although no studies have been performed on reproductive success on different spawning substrates, Danylchuk and Fox (1996) demonstrated a preference of female pumpkinseeds for nesting on firm substrates (sand or gravel) as opposed to soft substrates. In addition, severe disturbances (i.e. the removal of detritus and macrophytes) and the creation of new water bodies are likely to create conditions with few or no competitors and predators. Especially because nature managers strive to keep these waters free of fish, as they are known to have undesirable effects, such as bioturbation (Scheffer 1998), nutrient mobilization (Carpenter and Kitchell 1993) and predation 


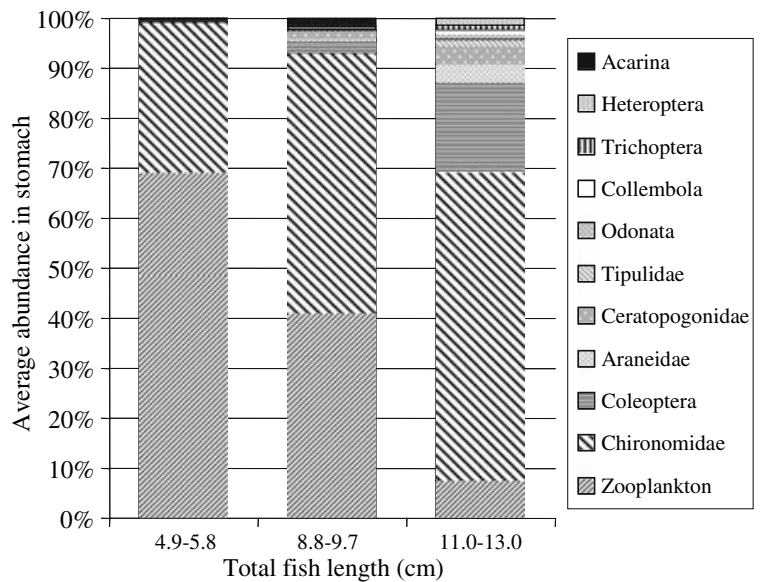

Fig. 4 Average relative numbers of invertebrate taxa in pumpkinseed stomachs from three different length classes ( $\mathrm{N}=6$ for each length class). Ranges of length classes are given

on larvae of amphibians (Smith et al. 1999). Fish diversity in moorland pools is further limited by acidification at the end of the 20th century when nearly $70 \%$ of the Dutch moorland pools acidified (Leuven et al. 1986b), strongly decreasing the number and abundance of fish species. Since 1980 deposition of acidifying substances has decreased resulting in a $\mathrm{pH}$ increase in many North European and Dutch moorland pools (Forsius et al. 2002; Van Dam and Mertens 2004) above levels toxic to fish (Baker and Schofield 1982).

Because pumpkinseed records in national and regional databases were gathered by volunteers and most records $(56 \%)$ were older than ten years, the influence of temporal and methodological variation may be substantial. This is even more likely in shallow isolated waters such as moorland pools, as they may completely freeze in sever winters and dry up in dry summers. Furthermore, at the moment of discovery populations may have been in different stages of development (Williamson 1996). The census of pumpkinseed abundance in 2007, however, revealed that estimation of pumpkinseed abundance from databases and other sources led to an overestimation in only 4 of the 27 sites. Apparently, pumpkinseed population densities in isolated waters are relatively stable and data from the consulted databases is sufficiently accurate for the analysis of distribution and abundance patterns. Given the national scale of the study, a substantial number of pumpkinseed populations will have been overlooked. Nevertheless, most of our abundance data consist of records of small numbers of pumpkinseed rather than large populations and thus appear sufficiently detailed for analysing patterns in pumpkinseed abundance.

The importance of pumpkinseed introductions by human as a dispersal mechanism is illustrated by the fact that Dutch isolated waters with pumpkinseed were more often located close to human habitation and infrastructure than could be expected based on the distribution of randomly selected isolated waters (Fig. 3). Copp et al. (2005) also found more occurrences of non-native species near roads and houses than expected. These findings also indicate that planning of nature management practices can best be done at distances over $250 \mathrm{~m}$ from human habitation and $100 \mathrm{~m}$ from roads and paths in order to minimize the chances of introductions. Further proof for voluntary introductions is provided by the occasional occurrence of common garden pond plants in Dutch waters with pumpkinseeds. Egg dispersal by waterfowl is unlikely, as pumpkinseed reproduction does not coincide with bird migration peaks. Egg dispersal by animal vectors is further limited due to a short egg stage (i.e. as short as 3 days in warm waters; Scott and Crossman 1973) and loss of adhesiveness as they become covered in sand and dirt by the swimming activity of the male (pers. obs. M.C. van Riel).

In Europe pumpkinseed are opportunistic predators (Godinho et al. 1997; Garcia-Berthou and Moreno-Amich 2000; Copp et al. 2002 and this study), feeding on the most frequent and abundant prey. Despite its invasive behaviour and opportunistic feeding, studies on the ecological impact of pumpkinseed are rare (Osenberg et al. 1992), speculative (Garcia-Berthou and Moreno-Amich 2000) or lack bibliography (Welcomme 1988). Introduced pumpkinseed have been reported to have a negative impact on native fish species (Welcomme 1988), dragonflies (Janssen 2000) and amphibians (Bosman 2003). We demonstrated that macroinvertebrate abundance in pools populated by large numbers of pumpkinseed was $83 \%$ lower than in pools without pumpkinseed. Of the abundant invertebrate taxa, only water mites (Acarina) appeared to be unaffected and comprised only a minor part of the diet, despite the fact that they are often larger than other prey such as zooplankton and chironomids. Lack of water mites in the 
pumpkinseed diet was also observed by Copp et al. (2002) and can be attributed to the distasteful secretions they shed to prevent predation by fish (Kerfoot 1982).

Currently there is little experience with pumpkinseed control. Promising is reducing the depth of colonized waters by filling them with soil in order to make them temporary. However, this method is not always feasible or desirable. Therefore other options need to be explored, such as introducing native competitors and predators and the use of biodegradable piscicides. Probably more important is reducing the number of introductions of pumpkinseeds. This requires limitation of the sale of the species and other measures to reduce introductions such as a growing public awareness of the ecological consequences of introducing invasive species, followed by an adequate control and enforcement of legislation concerning invasive species.

Acknowledgements The authors thank the following people and organisations for contributing data: J. van Delft, W. Bosman, L. Paulsen, F. Ottburg, H. de Nie, W. Verberk, N. Ettema, F. Spikmans, J. Klein Breteler, R. van der Burg, M. de Bijl, E. van Ingen, H. Kroodsma, P. van den Munckhof, Limens divergens, RAVON, OVB, Natuur Historisch Genootschap Limburg, Bureau van Nierop, Bureau Starop and It Fryske Gea. We are grateful to Prof. P.H. Nienhuis for providing comments that improved the manuscript.

Open Access This article is distributed under the terms of the Creative Commons Attribution Noncommercial License which permits any noncommercial use, distribution, and reproduction in any medium, provided the original author(s) and source are credited.

\section{References}

Arts GHP, Leuven RSEW (1988) Floristic changes in shallow softwaters in relation to underlying environmental factors. Freshw Biol 20:97-111

Arts GHP, De Haan AJ, Siebum MB, Verheggen GM (1989) Extent and historical development of the decline of Dutch soft waters. Proc K Ned Akad Wet C 92:281-295

Arts GHP, Van der Velde G, Roelofs JGM, Van Swaay CAM (1990) Successional changes in the softwater macrophyte vegetation of (sub)atlantic, sandy lowland regions during this century. Freshw Biol 24:287-294

Baker JP, Schofield CL (1982) Aluminum toxicity to fish in acidic waters. Water Air Soil Pollut 18:289-309

Bosman W (2003) Het Rauwven, een exotisch ven in het beekdal van de Aa. RAVON 15:33-36

Brouwer E, Roelofs JGM (2001) Degraded softwater lakes: possibilities for restoration. Restor Ecol 9:155-166
Carpenter SR, Kitchell JF (eds) (1993) The trophic cascade in lakes. Cambridge University Press, Cambridge

Casal CMV (2006) Global documentation of fish introductions: the growing crisis and recommendations for action. Biol Invasions 8:3-11

Copp GH, Fox MG (2007) Growth and life history traits of introduced pumpkinseed (Lepomis gibbosus) in Europe, and the relevance to its potential invasiveness. In: Gherardi F (ed) Biological invasions in inland waters: profiles, distribution and threats. Springer, Dordrecht

Copp GH, Fox MG, Kovác V (2002) Growth, morphology and life history traits of a cool-water European population of pumpkinseed Lepomis gibbosus. Arch Hydrobiol 155:585-614

Copp GH, Wesley KJ, Vilizzi L (2005) Pathways of ornamental and aquarium fish introductions into urban ponds of Epping Forest (London, England): the human vector. J Appl Ichthyol 21:263-274

Danylchuk AJ, Fox MG (1996) Size and age-related variation in the seasonal timing of nesting activity, nest characteristics, and female choice of parental male pumpkinseed sunfish (Lepomis gibbosus). Can J Zool 74:1834-1840

De Nie HW (1996) Atlas van de Nederlandse zoetwatervissen. Media Publishing, Doetinchem

Forsius M, Vuorenmaa J, Mannio J, Syri S (2002) Recovery from acidification of Finnish lakes: regional patterns and relations to emission reduction policy. Sci Total Environ 310:121-132

Garcia-Berthou E, Moreno-Amich R (2000) Food of introduced pumpkinseed sunfish: ontogenetic diet shift and seasonal variation. J Fish Biol 57:29-40

Godinho FN, Ferreira MT, Cortes RV (1997) The environmental basis of diet variation in pumpkinseed sunfish, Lepomis gibbosus, and largemouth bass, Micropterus salmoides, along an Iberian river basin. Environ Biol Fish 50:105-115

Gutiérrez-Estrada JC, Pulido-Calvo I, Prenda J (2000) Gonadosomatic index estimates of an introduced pumpkinseed (Lepomis gibbosus) population in a Mediterranean stream, using computational neural networks. Aquat Sci 62:350-363

Holčik J (1991) Fish introductions in Europe with particular reference to its central and eastern part. Can J Fish Aquat Sci 48(suppl 1):13-23

Hoogerwerf G, Voorn P, Ten Heggeler N (2005) Evaluatie van 4 vispassages in het beheergebied van het Waterschap De Dommel. Natuurbalans-Limes Divergens BV, Nijmegen

Janssen ICJM (2000) Monitoring van het Haeselaarsbroek in het brongebied van de Pepinusbeek. Ontwikkelingen in een natuurherstelproject in de Middenlimburgse gemeente Echt. Verslagen Milieukunde nr. 189, Radboud University, Nijmegen

Kelly CA, Rudd JWM, Furutani A, Schindler DW (1984) Effects of lake acidification on rates of organic-matter decomposition in sediments. Limnol Oceanogr 29: 687-694

Kerfoot WC (1982) A question of taste: crypsis and warning coloration in freshwater zooplankton communities. Ecology 63:538-554

Klaar M, Copp GH, Horsfield R (2004) Autumnal habitat use of non-native pumpkinseed Lepomis gibbosus and 
associations with native fish species in small English streams. Folia Zool 53:189-202

Leuven RSEW, Van der Velde G, Vanhemelrijk JAM, Eeken RLE (1986a) Impact of acidification on the distribution of aquatic insects in lentic softwaters. Proc. 3rd. European Congress of Entomology. Dutch Entomological Society, Amsterdam, pp 103-106

Leuven RSEW, Oyen FGF (1987) Impact of acidification and eutrophication on the distribution of fish species in shallow and lentic soft waters of the Netherlands - an historical perspective. J Fish Biol 31:753-774

Leuven RSEW, Wolfs WJ (1988) Effects of water acidification on the decomposition of Juncus bulbosus L. Aquat Bot 31:57-81

Leuven RSEW, Kersten HLM, Schuurkes JAAR, Roelofs JGM, Arts GHP (1986b) Evidence for recent acidification of lentic soft waters in the Netherlands. Water Air Soil Pollut 30:387-392

Leuven RSEW, Van der Velden JA, Vanhemelrijk JAM, Van der Velde $G$ (1987) Impact of acidification on chironomid communities in poorly buffered waters in the Netherlands. Ent Scand Suppl 29:269-280

Leuven RSEW, Van der Velde G, Kersten HLM (1992) Interrelations between $\mathrm{pH}$ and other physico-chemical factors of Dutch soft waters. Arch Hydrobiol 126:27-51

Looijen AJL (1948) De Nederlandsche Heidemaatschappij en haar bemoeiingen op visserij-gebied. In: De Nederlandsche Heidemij 60 jaar. Heidemij, Arnhem
Osenberg CW, Mittelbach GG, Wainwright PC (1992) Twostage life histories in fish: the interaction between juvenile competition and adult performance. Ecology 73: 255-267

Roelofs JGM (1983) Impact of acidification and eutrophication on macrophytes communities in soft waters in the Netherlands. 1. Field observations. Aquat Bot 17:139-155

Scheffer M (1998) Ecology of shallow lakes. Chapman \& Hall, London

Scott WB, Crossman EJ (1973) Freshwater fishes of Canada. Bulletin 184. Fisheries Research Board of Canada, Ottowa

Smith GR, Rettig JE, Mittelbach GG, Valiulis JL, Schaack SR (1999) The effects of fish on assemblages of amphibians in ponds: a field experiment. Freshw Biol 41:829-837

Trombulac SC, Frissell CA (2000) Review of ecological effects of roads on terrestrial and aquatic communities. Conserv Biol 14:18-30

Van Dam H, Mertens A (2004) Vennen in weer en wind: langetermijneffecten van verzuring en klimaatsverandering op chemie en kiezelwieren. De Levende Natuur 105:13-18

Welcomme RL (1988) International introductions of inland aquatic species. FAO fisheries technical paper no. 294. Food and Agriculture Organization of the United Nations, Rome

Williamson M (1996) Biological invasions. Chapman Hall, London, UK 